\title{
Collection System of Mandatory Employee Contributions (IWP) for Participants at PT. Taspen (persero) Serang Branch Office
}

\author{
Romi Agustiana ${ }^{1^{*}}$ \\ ${ }^{1}$ University of Sultan Ageng Tirtayasa, Indonesia \\ Corresponding-Author: romyagustiana@gmail.com ${ }^{1 *}$
}

Keywords : Employee Contribution, Billing System, Standard Operating Procedure

\begin{abstract}
:
The purpose of this study was to find out and obtain data regarding the Mandatory Employee Contribution (IWP) billing system for participants managed by PT. TASPEN (Persero) Serang Branch Office, as well as providing information to the participants of the pension program and Old Age Savings (THT) how the process or flow goes through in collecting the Mandatory Employee Contribution (IWP) for these participants. The results of the study indicate that the Mandatory Employee Contribution (IWP) billing system for participants at PT. TASPEN (Persero) Serang Branch Office which has been created and implemented in the Company Operational Standards (SOP) has been explained in detail and has been implemented properly in accordance with the system created.
\end{abstract}




\section{Introduction}

In this very rapid economic development, causing increased economic growth in a person so as to provide awareness to achieve a better quality of life. For example, it can be seen from the attitudes and actions of almost some people who want their lives to be prosperous, while they are still active at work or when they are entering retirement at an advanced age. They want a guarantee in the continuity of their welfare when they are no longer working. Therefore, they need service compensation, namely the existence of a pension program or Old Age Savings (ENT) as a solution in overcoming the problems of living welfare of each individual. One of the service companies that handle retirement programs or Old Age Savings (ENT) is PT. TASPEN (Persero) Serang Branch Office.

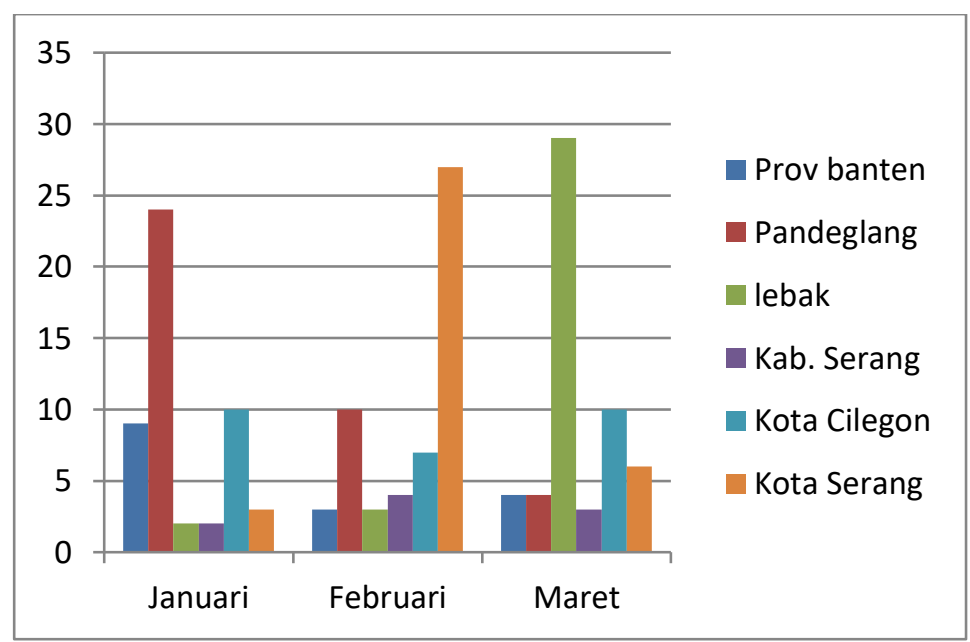

Source: PT. TASPEN (Persero) Serang Branch Office

Figure 1. Local Government Payroll Delivery Diagram

From the diagram of sending the local government payroll to PT. TASPEN (Persero) Serang Branch Office for the collection of Mandatory Employee Contributions (IWP) that there are several local governments that send data in the form of a list of salaries for local government employees that do not match the predetermined date, namely on the 25th of each month. So the delay in sending the payroll can hamper the performance of employees in collecting the Mandatory Contributions), one of which triggers delays, namely in the reconciliation in the payroll and will slow down the performance of employees of PT. TASPEN (Persero) Serang Branch Office in making a dues bill, and will have an impact on the delay in paying the bill to the local government.

These problems will have a continuous impact on the performance carried out at PT. TASPEN (Persero) Serang Branch Office. And it will also have an impact on the monthly reporting to the head office. This problem will lead to a bad assessment of the branch office. Therefore, internal control must be good enough to deal with these problems. If a local government and kppn experience delays in sending payroll data, employees at PT. TASPEN 
(Persero) Serang Branch Office makes an estimate of the salary list from the previous data and will be adjusted again with the latest data.

If the salary data is lacking in terms of contributions, PT. TASPEN (Persero) Serang Branch Office will make a bill of lading. And if the salary data or bill payments are in excess or after being checked, there are participants who have retired but are still paying their contributions to PT. TASPEN (Persero) Serang Branch Office. Then the payment of the dues must be returned to the local government or KPPN concerned.

Before collecting dues to each collaborating agency, PT. TASPEN (Persero) Serang Branch Office at the latest on the 25th of each month to collect, record and reconcile data on the collection of Employee Compulsory Contribution (IWP) for participants. This is a system carried out by PT. TASPEN (Persero) Serang Branch Office to collect contributions to the agency. The fields or divisions involved in implementing this fee collection system are not only one field, but two fields, namely the field of financial administration and the field of participation. However, the person responsible for collecting, recording, and reconciling the Mandatory Employee Contribution (IWP) is in the field of financial administration.

In collecting the Mandatory Employee Contribution (IWP) at PT. TASPEN (Persero) Serang Branch Office, in the field of Participation, collecting salary data and recap. The collection of salary data and recapitulation serves as a recap of the estimated bill for the Employee Compulsory Contribution (IWP) to the Financial Administration section. And then the Financial Administration section sends a dues bill to the local government, the local government will reply by providing the latest salary data every month. Then the Participant and Financial Administration section reconciles the salary data. If there is a change then the database must be changed. In order to avoid errors in the collection of the Employee Compulsory Contribution (IWP).

Collection of contributions is one way to obtain company income. At PT. TASPEN (Persero) Serang Branch Office income can be in the form of Government Funds, namely from the APBN, investment income, and income that is prioritized for contributions from participants, namely Work Accident Insurance (JKM), Death Insurance (JKM), Old Age Savings (THT) and The contribution pension program is combined and becomes the Employee Compulsory Contribution (IWP). In order for the pension program and Old Age Savings (THT) to run properly, the funds obtained are not only from the government, because of the remuneration for their service to the state but there is an additional contribution paid every month. For this reason, the company must implement a fee collection system, namely by recognizing contributions as receivables, because receivables can be interpreted as bills that can only be settled by receiving payments in the future. Therefore, it is necessary to have a dues collection system so that it does not result in uncollected contributions.

In addition to causing uncollectible contributions, delays in making the payment of the Mandatory Employee Contribution (IWP) can affect PT. TASPEN (Persero) Serang Branch Office. One of the effects is that it can hinder the performance of PT. TASPEN (Persero) Serang Branch Office, especially the Division of Financial Administration in making monthly reports 
which are carried out every month to the Head Office. In addition, if the delay continues, it will affect the performance appraisal of each Branch Office when reporting monthly reports to the center. Although until now PT. TASPEN (Persero) Serang Branch Office has used a computerized system and is in accordance with Financial Accounting Standards and running well, but there are still problems in collecting the Mandatory Employee Contribution (IWP).

In view of the collection of the Mandatory Employee Contribution (IWP) for participants at PT. TASPEN (Persero) Serang Branch Office comes from a combination of two programs, namely the pension program and the Old Age Savings (ENT) program, although the system used by PT. TASPEN (Persero) Serang Branch Office has been running well but there are still problems or obstacles that are felt when collecting the Mandatory Employee Contribution (IWP). The problem is the delay in sending salary data from each local government, when recording the SSBP which is still manual and the process is too long and repetitive, causing it to be insignificant and inefficient in terms of working time. So the author is interested in discussing the Billing of Mandatory Employee Contributions (IWP) for participants in addition to knowing the billing system used, This research is useful as information for participants of the Pension and Old Age Savings (THT) program who want to know how to systematically collect Employee Compulsory Contributions (IWP) for participants. To find out more, the author will put it in and explain it in an article entitled "MANDATORY EMPLOYEE CONTRIBUTION BILLING SYSTEM (IWP) FOR PARTICIPANTS AT PT. TASPEN PERSERO SERANG BRANCH OFFICE".

The billing system is a procedure made by the company as a guide in collecting contributions to participants who have been registered in the pension and Old Age Savings (THT) program organized by companies in the service sector, such as insurance companies. In collecting contributions, it can be recognized as receivables, therefore there is an acknowledgment of receivables in collecting. The purpose of the billing system is to assist companies in obtaining their rights to contributions so that the company's operational activities run well and smoothly. With the creation of a billing system, it will make it easier for billing employees to carry out their duties. According to Mulyadi (2016:411) the billing procedure is carried out as follows: (1) The accounts receivable section provides a list of receivables that are due to be billed to the collection department; (2) Part billing sends the collector, who is an employee of the company, to collect the debt from the debtor; (3) The collection department receives a check in the name and a remittance advice from the debtor; (4) Part billing hand over the check to the cash division; (5) The billing department submits a notification letter to the accounts receivable department for the purpose of posting to the credit card; (6) The cash department sends a receipt as a sign of cash receipts to the debtor; (7) Cash section depositing checks in bank (8) Bank the company clears the check to the debtor's bank.

According to Mulyadi (2016:407) the related functions in the cash receipts system from receivables are the Secretariat Function, Collection Function, Cash Function: This function is responsible for receiving checks from the secretariat function (if cash receipts from 
receivables are carried out by post) or from the billing function (if cash receipts from receivables are carried out through company collectors). The cash function is responsible for depositing cash received from these various functions immediately to the bank in full. Accounting Function: Responsible for recording cash receipts from receivables into the cash receipts journal and reducing receivables into accounts receivable cards. Internal Audit Function: In the cash receipts system from accounts receivable, the internal audit function is responsible for carrying out periodic cash calculations on the cash function. In addition, the internal audit function is responsible for conducting bank reconciliations, to check the accuracy of cash records maintained by the accounting function

\section{Research Method}

The object of writing this final project is the Mandatory Employee Contribution Billing System (IWP) at PT. TASPEN (Persero) Serang Branch Office. Which is located on Jl. KH Abdul Fatah Hasan No. 80, Cipare, Kec. Serang, Serang City, Banten 42117. In collecting the object of writing the final project using a descriptive method, for this type of data the author uses primary and secondary data to complete the data used. The data obtained are from field studies and literature studies. For data collection using the interview method.

\section{Results and Discussion}

On the results of the internship that has been discussed by the author, the Mandatory Employee Contribution (IWP) in PT. TASPEN (Persero) Serang Branch Office can be recognized as receivables, because the local government or kppn pays dues to PT. TASPEN (Persero) Serang Branch Office and will be recognized as cash or assets by the company. Therefore it can be considered as cash receipts from receivables through the company's collectors. Because receivables are company assets, a good Employee Compulsory Contribution (IWP) collection system is needed so that the company's operational activities continue to run properly.

The following are the details of the research results of the Mandatory Employee Contribution (IWP) billing system for participants at PT. TASPEN (Persero) Serang Branch Office:

1. Compulsory Employee Contribution (IWP) billing system for participants

The collection occurs due to a dues bill due to payment transactions made by the local government or KPPN to PT. TASPEN (Persero) Serang Branch Office which gives rise to the recognition of receivables and for the company is considered as cash receipts. The collection of these fees arises because of the activities carried out by PT. TASPEN (Persero) Serang Branch Office in terms of payment of contributions to pension program participants and Old Age Savings (THT) which is managed by the local government and KPPN of the service area, and the contributions will be managed by PT. TASPEN (Persero) Serang Branch Office which will become social security if the participant's term of service or work period has ended. 
PT. TASPEN (Persero) Serang Branch Office recognizes contributions as receivables because contributions are one of the company's revenues that must be collected, therefore contributions are recognized as receivables. In theory according to (Martani 2018:204) the recognition of receivables can be recognized when the company has recognized its revenue, the company will recognize the receivables.

Once recognized as a receivable, the contribution will be billed by the company in accordance with the receivable collection procedure. In the receivable collection procedure carried out by PT. TASPEN (Persero) Serang Branch Office is different from the theory according to Mulyadi (2016:411) that the receivable collection procedure is on cash receipts starting from the accounts receivable section then to the billing section, then to the cashier section and finally to the journal section. While at PT. TASPEN (Persero) Serang Branch Office, the billing procedure has 5 stages and is carried out by 2 parts, namely the membership section which collects softcopy of salary data, and then prints a list of bills. The financial administration department creates \& sends invoices, keeps journals, and makes receipts vouchers.

There is a difference in the receivable collection procedure according to Mulyadi's theory with the receivable collection procedure at PT. TASPEN (Persero) Serang Branch Office. If the receivables collection procedure according to Mulyadi there are 4 parts that are passed, while at PT. TASPEN (Persero) Serang Branch Office went through 2 parts and there were 5 stages that occurred during the receivables collection process, starting with the participation section by collecting salary data then comparing the salary data with the latest participant salary recap, then making a recon to the local government, after being approved by the division the membership prints a list of invoices which are then submitted to the financial administration section. In the finance department, it starts with making and sending invoices, then the journal acknowledgment of receivables, after receiving the deposit and making a recon, then create a receipt voucher. Basically what distinguishes Mulyadi's theory from PT. TASPEN (Persero) Serang Branch Office is in its stages which has 5 stages in the receivable collection procedure, namely the stage of collecting salary data, printing a list of bills, making \& sending invoices, journaling, and the stage of making receipt vouchers.

In the Mandatory Employee Contribution (IWP) collection system, after being recognized as a receivable, a receivable collection procedure will be carried out, at PT. TASPEN (Persero) Serang Branch Office begins with the stage of collecting salary data carried out by the membership department, after collecting and conducting research on the truth of salary data, then uploading salary data and comparing the uploaded recap with the participant's salary recap. After that, do data approval with the latest data from the local government and KPPN. Then the membership section makes a list of bills and submits it to the financial administration section.

After receiving a list of invoices from the membership section, the finance department prepares and sends invoices to the regional government and KPPN, then the contributions are recognized as receivables and make a journal of acknowledgment of receivables. Then 
collect/receive IWP deposits. Then do research and match the SSBP with attachment IV from the local government, after that make a recording of the SSBP, NTPN, and attachment IV from the local government. Then make corrections to the recognition of receivables at the beginning of the month based on the recap of the correction listing from the membership. Furthermore, to reconcile between SSBP and DBI, if there is a difference, then confirm, follow up on confirmation results, receive an abundance of premium realization from the treasury division. Comparing the realization of contribution receipts with the recording of SSBP, following up if there are differences.

2. Problems That Occur When Collecting Mandatory Employee Contributions (IWP)

In the process of collecting the Mandatory Employee Contribution (IWP) at PT. TASPEN (Persero) Serang Branch Office has been well systematized but there are still obstacles in its implementation. The following are some of the problems faced in collecting the Mandatory Employee Contribution (IWP) at PT. TASPEN (Persero) KC. Attack:

a. When collecting IWP deposits by the membership division, the collection must be submitted every 5th of every month to the membership division, but when collecting the latest salary data from each local government, if the local government experiences delays in sending salary data it will have an impact on collecting IWP deposits .

b. In the process of collecting dues at PT. TASPEN (Persero) KC. Serang has been systematized and computerized, but recording SSBP to the head office is still manual by inputting data one by one, this is because the local government does not send data that is not computerized.

c. The participation section synergizes in the process of collecting Mandatory Employee Contributions (IWP), the participation section plays a role in rejuvenating participant data in the form of salary data. Because the process is so long and repetitive, it causes the process to be ineffective.

\section{Conclusion}

The conclusions of this research include the Mandatory Employee Contribution (IWP) billing system for participants at PT. TASPEN (Persero) Serang Branch Office which has been created and implemented in the Company's Operating Standards (SOP) has been explained in detail and has been implemented properly according to the system created. In a system it is impossible for problems to occur even though the system has been computerized, the problems that occur can be from errors made by employees who do billing, by computer systems that sometimes error or from systems that are so complicated that will cause the problem to occur.

Suggestions from the author in carrying out the billing process must be more thorough and the process must be made easier so that there are no more mistakes, rounding up in making it easier to calculate salaries must be in accordance with the policies set. In addition, in future research, continuous research can be carried out on the same object and conducting research on different objects. 


\section{Acknowledgment}

Acknowledgments are conveyed to the Diploma Three Accounting Study Program, Faculty of Economics and Business, University of Sultan Ageng Tirtayasa.

\section{References}

Carl S. Warren, James M. Reeve, Jonathan E. Duchac, Ersa Tri Wahyuni, Amir Abadi Yusuf. 2017. "Introduction to Accounting 1 - Adaptation of Indonesia Empathy Edition". Jakarta: Salemba Empat

Hutahaean, Jeperson. 2015. "The Concept of Information Systems". Yogyakarta: Depublish

Indonesian Institute of Accountants. 2017. Financial Accounting Standards: Effective as of 2017. Salemba Empat: Jakarta

James, C et al. 2016. "Principles of Financial Management". Jakarta : Salemba Empat

Decree of the Minister of Finance Number: 343/KMK.017/1998 Regarding Contributions and Contribution Benefits

Maniah, Dini Hamidini. 2017. "Analysis and Design of Practical Discussion Information Systems with Case Examples". Yogyakarta: Depublish

Margaretha, Farah. 2007. "Financial Management for Industry \& Services". Jakarta: Grasindo.

Martini, Dwi. Siregar, Veronica, Sylvia. Wardhani, Ratna. Farahmita, Aria. Tanujaya, Edward. 2018. "Medium Financial Accounting Based on PSAK" Sixth Edition. Jakarta: Salemba Empat

Mulyadi. 2016. "Accounting System Edition 4". Jakarta: Salemba Empat

Minister of Finance Regulation Number: 226/PMK.05/2016 concerning the Second Amendment to the Regulation of the Minister of Finance Number: 222/PMK.05/2014 Regarding Third Party Calculation Funds

Ratna, Amelia. 2017. Accounting Treatment of JKK JKM Contribution Income at PT TASPEN (Persero) Bandar Lampung Branch. (http://eprints.jeb.polinela.ac.id/296/1/Jurnal_Amelia\%20Ratna\%20Ramadhani.pdf) , (accessed February 5, 2020)

Romney, Marshall B. and Steinbart. 2015. "Accounting Information System 13th edition, transliterated: Kikin Sakinah Nur Safira and Novita Puspira". Jakarta : Salemba Empat 
Sari, Hesty Puspita. et al. 2017. Application System for Processing Report Values at SDN Tanjunganom 2 Tanjunganom Nganjuk District. "Scientific Journal of Informatics Engineering". (Volume 11;1).

Sudaryono. 2016. "Marketing Management". Yogyakarta: Andi Publisher

Suryani \& Hendryadi. 2015. "Quantitative Research Methods Theory and Applications in Research in the Field of Management and Islamic Economics". Jakarta: Prenada Media Group.

Widodo.2017. "Research Methodology, Popular \& Practical. Jakarta: PT Raja Grafindo Persada. 